\title{
Education Development Goals (EDGs) and Socio-economic Democratic Consolidation: Reflections on Regime's Mandates, Objectives, Agendas, and Targets in Yobe State, Nigeria
}

\author{
Ali Ibrahim Abbas (Corresponding Author) \\ Department of Government \& Civilisation Studies, \\ Universiti Putra Malaysia, 43400, Serdang, Malaysia \\ $\&$ \\ Department of Political Science \& Administration, \\ Yobe State University, PMB 1144, Damaturu, Nigeria \\ Tel.: 60-102-971-774, 234-803-691-9495Ｅ-mail: alibrahimabbas2000@gmail.com
}

\begin{abstract}
Ku Hasnita Binti Ku Samsu
Department of Government \& Civilisation Studies, Universiti Putra Malaysia, 43400, Serdang, Malaysia Tel.: 60-192-197-677Ｅ-mail: hasnita@upm.edu.my
\end{abstract}

Adlina Binti AB Halim

Department of Government \& Civilisation Studies, Universiti Putra Malaysia, 43400, Serdang, Malaysia Tel.: 60-192-990-071Ｅ-mail: adlina@upm.edu.my

Mohammed Bashir Saidu

College of Business Administration, Universiti Tenaga National, Pahang Campus, Malaysia Tel: 60-163-830-944Ｅ-mail: mbsaidmayo@yahoo.com 
Received: July 10, 2017 Accepted: August 14, 2017 Published: August 16, 2017

doi: 10.5296/jsss.v5i1.11526

URL: http://doi.org/10.5296/jsss.v5i1.11526

\begin{abstract}
Education development is now considered an important element in combatting poverty, exploitation and promoting democracy. Hence, it not surprising that at global and local levels there have been rapid but in some cases, the gradual transformation of education development system spearheaded by governments and development bodies through policy formulation and implementation. In Nigeria, this development is however diverse as each sub-national levels depicts a different scenario in the country. Since the creation of Yobe state in 1991 during the military regime up to 1999 when democracy was restored across the country, the state has been tagged as an "Educationally Disadvantaged State" (EDS). Yobe had, therefore, continued to battle with efforts to reforms its educational system both in theory and practice. This paper describes and analyses the pursuit of Education Development Goals (EDG) from 2009-2015 by Governor Gaidam's regime in Yobe state, Nigeria as a tool for socio-economic democratic consolidation in the state. The narrative is based on perceptions and experiences of education stakeholders in the state. This qualitative study involved 28 interviews interview with key informants and the review of various policy documents, which intend to underscore the real essence for and modality of pursuing the EDGs by this regime. The study delineates the state government's mandates, strategic objectives, agenda and target setting towards achieving overall education development under this democratic regime. Emphasis has been laid on the process, content and context of the regime's key development agenda which may either positively or negatively affect the state's nature of socio-economic democratic consolidation.
\end{abstract}

Keywords: Politics, Development, Education goals, Agenda setting, Socio-economic, democratic consolidation, Yobe state, Nigeria

\title{
1. Introduction
}

Based on the recent perspectives, education is considered as fundamental human right (Sen \& Mukherjee, 2014; Chatterji, Mohan, \& Dastidar, 2015; UNESCO, 2015; Anyanwu, 2016) and thus the influence of public investment in education development is becoming much more important (Scheerens, Luyten, \& Ravens, 2011; Lewin, 2015; Socci, Ciaschini \& Toffoli, 2015; Anyanwu, 2016) particularly for developing nations and democracies. Based on this, the right of citizens to basic education now is considered as a fundamental objective principle for democratic governments as it remains essential towards the achievement of the social, economic and political development of most societies. Further, education development is also an important element in combatting poverty, exploitation and promoting democracy (Tickly, 2011; Tickly \& Barret, 2011; USAID, 2011; Shimeles \& Verdier-Chouchane, 2016). It is therefore not surprising that at global, national and even local levels there have been rapid but in some cases, the gradual transformation of education development system spearheaded by both governments and development bodies.

Since the return of democracy in Nigeria in 1999, most of the nation's education development 
goals have similarly been affected at national and sub-national levels by the current global trend with an emphasis on improving access, quality and equality. As a derive towards achieving these key objectives, each level of democratic governance structure thus needs to perform towards initiating and implementing it desired education development goals in line with the international best practices. This is particularly important for Nigeria as it remains a member state of education-related international conventions and agreements. It includes Universal Declaration on human rights; international convention on rights of children; international covenant on civil and political rights; international covenant on economic, social and cultural rights; and convention rights of people living with disabilities, etc. Infact, it was the same agreements that led to the introduction of various international education development goals (IEDGs) such as the Education for All (EFA) and other education related goals such as in the Millennium Development Goals (MDGs).

Beyond the general provision at the global level, the Federal Government of Nigeria (FGN) had equally adopted important IEDGs at the national level. In specific, Nigeria's National Policy on Education (NPE) like the education-related MDGs have emphasised the attainment of Universal Basic Education (UBE) by the year 2015 in Nigeria. The National Economic Empowerment and Development Strategy (NEEDS) a Nigeria's sort of development agenda had also captured education as one of its core pillars of socio-economic development under current democratic dispensation. In fact, this development agenda was consistent with the Nigeria's intentions when it introduced UBE program since the return of democratic rule in 1999. Therefore, since the passage of the UBE Act into law in 2004 in Nigeria, all the 36 state governments and the Federal Capital Territory (FCT) in line with the national education development agenda were therefore mandated to initiate and implement such educational policies for the overall development of the education system of the nation.

In Yobe state, while efforts were made by previous democratic regimes to improve its educational system, available statistics showed that the state over the years remains one of the most backward in education development in Nigeria (NPC \& ICF Macro, 2008). This report is not at all surprising at it depicts why for instance over the years, Yobe has always been tagged an educationally disadvantaged state. To buttress this point, the Nigerian Demographic and Health Survey further showed that women aged 15-49 years, $80.8 \%$ never attended school at all in Yobe state with only 5.6\% completed primary, 3.6\% completed secondary education and only $0.9 \%$ had more than secondary education (NPC \& ICF Macro, 2008). Even more worrisome is when such figures are compared with only $0.9 \%$ of the population of women in Imo state which had no education. Similarly, Delta and Anambra states had only $4.0 \%$ and $1.5 \%$ respectively that had no education (NPC \& ICF Macro, 2008). This poor situation of the education sector in Yobe state remained challenging to it overall socio-economic democratic consolidation as student's enrollment, retention, and completion rate were much lower than the national average. This poor education situation in Yobe state thus becomes a thing of serious concern not only to the current democratic regime but also to all well-meaning citizens and education stakeholders.

On the assumption of office in 2009, this regime maintained that it will initiate and implement priority EDGs in addressing existing education deficiencies associated with the education sector (YBSG, 2012). To indicate its importance towards achieving socio-economic 
democratic consolidation, USAID (2011) advanced that education has been an important component of a democratic state. Infact, in Yobe state, the lack of basic needs (education and health care) had continued to cause poverty, hunger, disease, unemployment, illiteracy, and youth restiveness (Abbas 2016). Hence, the sustainability of nascent democracies, especially in such developing societies, depends on education provided for all its citizens. Hence, the advancement of the argument by USAID (2011) that education development in many developing countries is now decentralising as political and administrative decentralisation is expected to promote more opportunities for citizens and civil groups to provide direct control and ensure accountability in the provision of educational services. Given the current importance and relevance that state governments play in the current Nigeria's decentralised education development and systems in achieving socio-economic democratic consolidation, a careful understanding is therefore needed not only for the goals but the realities on what, how and why certain EDGs are developed in the current democratic governance structure.

Although there have been previous discourses on international and national EDGs, there has been little evidence over EDGs at the sub-national level (state government), especially in Nigeria. Hence, exploring such important but often neglected EDGs as Pranevičienè and Margevičiūtè (2015) described it may "inspire dialogue within society, which may result in positive outcomes for both the people and the state (110)." Similarly, Socci et al. (2015) advanced that education is an important policy variable that promotes the socio-economic wellbeing of citizens in both developed and developing nations and democracies as it has multiplier effects on both medium and short term socio-economic development. Based on this, it is therefore important to understand what the current outcome is in EDGs as certain efforts in an educationally disadvantaged state like Yobe state in Nigeria could have been made through the current democratic governance process. This study, through the lenses of socio-economic democratic consolidation, therefore, made effort to provide the description and analysis of EDGs of the regime from 2009-2015 through the perceptions and experiences of key education stakeholders in the democratic process in Yobe state.

\section{Study Area and Methods}

The study was conducted in Yobe state described as one of the educationally disadvantaged states (EDS) in Nigeria with the regime's first tenure from 2009-2015 as the case in point. Located in North Eastern region of Nigeria, Yobe state was carved out from old Borno state on 27th August 1991. Yobe state is situated within latitude and longitude 11o N and $13.50 \mathrm{E}$ respectively with $47,153 \mathrm{~km} 2$ total land area. According to 2006 national population census figures, Yobe state has a population of 2,321,339 people made up of 1,205,034 male and $1,116,305$ female (NBS, 2010). Based on the projected 3.2\% growth rate per annum, Yobe's population currently ranges around 3.5 million with children under5 constituting about $20 \%$ (NBS, 2010). With 80\% rural population, Yobe state has 17 Local Government Areas (LGAs) and 178 political wards characterised by acute or poor social and economic infrastructure that may improve their current poor standard of living of its population including its educational system.

To understand the effort made by this regime towards developing its EDGs considered as foundational to overall education development in Yobe state, this study utilised qualitative research approaches. This approach adopted in the current study was considered appropriate 
because it offered an in depth views on the various aspects covered in the regime's response to education development in the current democratic governance process in Yobe state. The data collection was carried out in Yobe state, Nigeria from May to September 2016. The process includes reviewing of the regime's education policy documents and interviewing with purposively selected 18 informants. The interview data were later verified through member checking.

The 28 informants were selected from 3 categories of education administrators, practitioners and the civil society. For education administrators, it involved past and present politicians and bureaucrats with current or previous portfolios in State Ministry of Education (SMoE). In the case of education practitioners, school heads (principals and head masters) and teachers were involved. For the civil society, it involved representatives of various education related union bodies such as the Nigeria Union of Teachers (NUT) and Academic Staff Union of Universities (ASUU). In addition, some parents, women and youth's groups, media, traditional, religious and community leaders "who influenced or participated in education policy development in diverse context" (Barret, 2011) in Yobe state were interviewed as key informants in the study.

For data analysis, the thematic analysis approach to qualitative research was deployed where coding and categorising of major themes were achieved on the interview transcripts and notes. After codes were assigned, they were categorised in to broader themes based on frequency. The emergent themes were "the constitution and the decentralisation of the education system, strategic objectives, priority agenda setting and target setting." In addition, sub themes that emerged within each category were further analysed within each major themes. Although various efforts were made to cover education stakeholders, only the reflections, experiences and reports in the current democratic governance process were used in this study as there have been no abundant studies on this issue, especially in the study area. However, an understanding of the general education development approach of Nigeria and similar other places helps in identifying the overall development of education goals as is considered useful and applied in this study.

\section{Results and Discussions}

\subsection{Nigeria's Constitution and the Decentralisation of the Education System}

Most informants emphasise that the state governments in Nigeria are partly responsible for providing the education needs of its citizens in their respective territories. This means that since education is an important element that facilitates socio-economic development (Barret, 2011; Barret \& Tickly, 2011; USAID, 2011; Phuong Luong \& Wolfgang, 2014; Unterhalter, 2014; Lewin, 2015; Anyanwu , 2016; Shimeles \& Verdier-Chouchane, 2016) every state government in Nigeria must therefore properly develop its specific education goals to better its education system. With the civilian administration which Nigerians for long have aspired for (Abbas, 2013) and its current importance, informants shared that this current democratic regime is therefore expected to live to its duties and responsibilities towards providing the citizens with the qualitative, quantitative and functional education system, especially for all the school-aged children.

Related to the above approach is that informants emphasised the constitutional duties and 
responsibilities of the state government with regards to rights of citizens to basic education in democracies. Interestingly, this opinion is indicative of "the fundamental objectives and directive principles of state policy" on education across Nigerian states, including Yobe state. Specifically, the state educational objective founded on the principles of justice, equality and freedom as captured in chapter 2 subsection 18 (1-3) of the 1999 constitution of Nigeria requires that governments shall:

...direct its policy towards ensuring that there are equal and adequate educational opportunities at all levels; promote science and technology, and strive to eradicate illiteracy. The government shall as and when practicable provide (a) free, compulsory and universal primary education; (b) free secondary education; (c) free university education; as well as (d) free adult literacy program.

Based on above sections of the Constitution, it is therefore mandatory for democratic regimes in Yobe like in other states in Nigeria to provide educational opportunities for the overall well-being of its citizens and the society in general. This finding not surprising as education is now considered at the center stage of development considered as fundamental human right (Sen \& Mukherjee, 2014; Chatterji et al., 2015; UNESCO, 2015; Anyanwu, 2016) that is even more expected of democratic regime to deliver. Hence, the provision of education by the state is seen as an element that underscores social justice that must be "inclusive, relevant and democratic" (Tikly \& Barret, 2011). As social justice emphasises fairness and advocates affirmative action especially for the vulnerable groups in society such as poor persons, the absence of rights to education through a social welfare approach, most orphans in school would drop out of school as there is no help or sponsorship from relatives to solve demands of fees, clothing, books and other related education needs (Susuman, 2017). Hence, for education to be truly inclusive and relevant within the democratic consolidation framework in Yobe state, the EDGs are expected to be subjected to public and democratic contribution through the involvement of relevant stakeholders at all levels of the democratic governance structure.

Based on the earlier assertion, the contending point is that education is considered "value based, contextually and culturally contingent activity that fundamentally shapes the lives of individuals and the societies in which we live" (Barret, 2011: 146). This means there is a need for emphasis on the content, context, structure and political process beyond international and national boundaries to even sub-national levels. Importantly, as education reflects on the concurrent legislative list in the constitutional provision of the Federal Republic of Nigeria, Yobe like all other state governments is thus empowered to initiate and implement its specific EDGs in line with Nigeria's National Policy on Education. The main objective of the nation's education policy was to attain universal basic education by 2015 as envisaged in the MDGs. This means that Yobe like other state governments in Nigeria in their respective domains remains key player that could shape the characteristics of democratic arrangement that underpins its education development success or failure. This means certain efforts have to be put in place to ensure its success.

It was based on the above-mentioned context that the State Ministry of Education (SMoE) has been established and run as the bedrock for policy formulation and implementation of education at the state level. While this remains the general trend across the country, findings 


\section{Macrothink}

show that the institutional and management structure in Yobe state had not been consistent over the years. For instance, until July 2015 there were two ministries in charge of the education sector. One Ministry of Education was in charge of basic education (primary and secondary schools) and another Ministry of Higher of Education was in charge of tertiary institutions. Afterward, the two ministries were however merged and are currently referred to as the SMoE that provides overall functions to the entire education sector. To perform its routine functions, the SMoE under the leadership of Honourable Commissioner who remains a political appointee of the state executive governor is usually assisted by the Permanent Secretary (a senior career civil servant) and heads of departments, boards, and agencies in the education sector. Figure 1 below shows organogram of Ministry of Education (MoE) in Yobe state that is responsible for setting EDGs.

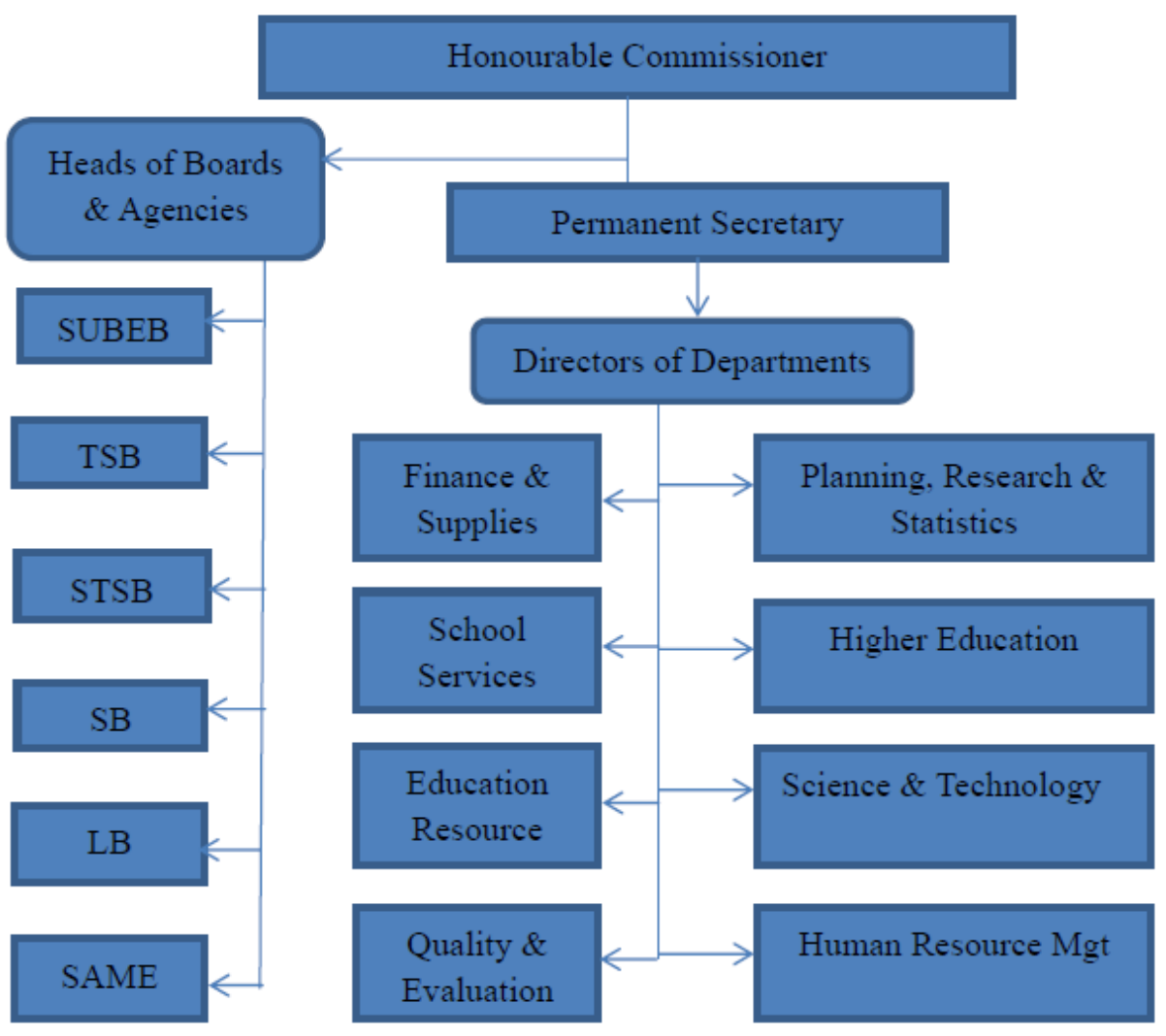

Figure 1. Organogram of the State Ministry of Education (SMoE) in Yobe state

Apart from the overall function the SMoE plays in policy formulation and implementation, the ministry in Yobe state also shares responsibilities and functions in collaboration with its key departments, boards, and agencies (Figure 1). These include the State Universal Basic Education Board (SUBEB), Teaching Service Board (TSB), Science and Technical Schools Board (STSB), Scholarship Board (SB), State Agency for Mass Education (SAME) and Library Board (LB) (YBSG, 2014). Specifically, TSB is in charge of overall management such as recruitment, training, promotion and discipline of teachers at senior secondary schools in the state. STSB is in charge of science, technical and vocational schools with 
similar functions as earlier mentioned for TSB. Also, SUBEB is responsible for management of basic education (primary and junior secondary schools) in addition to nomadic, almajiris and Tsangaya schools in the state. This means that each MDA work in tandem with the policy decision of the mother ministry.

Based on the above education development arrangement in Nigeria, certain education goals indicate decentralised decision making towards improving the management of the education system. It is in this regards that Carson, Noronha, and Trebilcock (2015: 24) showed that "country's decentralized education system allows for states and municipalities to serve as national laboratories for innovative educational programming." Hence, the success or failure of a democratic regime in Yobe state on how it efficiently managed educational challenges through proposed key EDGs is to be determined by the nature of its initiatives and plans in the education sector. Within this context, it means that the state governments through its SMoE will have to improve its major roles, responsibilities and functions towards ensuring these educational mandates are efficiently delivered by the democratic regime in power. Within the framework of socio-economic democratic consolidation, this regime's EDGs cannot be achieved however if its education objectives are not well articulated towards achieving its overall education development agenda.

\subsection{Education Strategic Objectives: Vision and Mission}

"Our desire is to lay the solid and firm foundation for the reactivation of the education sector in our beloved state to conform to the current challenges of development. This I believe is in keeping with our desire of achieving the set targets of the MDGs... I would like to assure you that, this administration would leave no stone unturned in its effort to provide qualitative and functional education to the people of the state especially to the underprivileged members of the society. This has been a deliberate government policy to further boost the education sector in the state so that in no distant future, Yobe will take its rightful position in the field of education in the Federation." (Address by H.E, Executive Governor of Yobe state, Alhaji Ibrahim Gaidam on the occasion of commissioning ceremony of phase I of Yobe-Turkish International College, Mamudo on $23^{\text {rd }}$ February 2009).

From the above remark, it seems that since the inception of this regime in 2009, the education sector in Yobe state was in need of urgent attention due to the unimpressive performance of Yobe students in Senior Secondary School Certificate Examinations. This unfortunate situation becomes worrisome even though in spite of the increased number of candidates sitting for the examination, the number of candidates that usually obtained the minimum entry requirements into institutions of higher learning to fill the state quota across the nation remained low (YBSG, 2012). As argued by the informants, although various attempts were made by successive democratic regimes in saving the educational system from total collapse, much is still left to be desired. In order to reverse this trend, the regime's vision and mission statement towards education development in Yobe state is captured in YOSERA document indicated below.

\section{Vision}

To increase enrollment rate into primary schools; increase capacity of schools to cope with increased enrollment; increase enrolment rate in secondary schools; reduce secondary school 
drop-out rate; increase transition rates from primary to junior/secondary schools in order to achieve greater placement rate in higher education levels to enable Yobe state fill its quota in tertiary institutions in the country (YOSERA III, pp. 58-9).

\section{Mission}

To ensure the provision of qualitative, functional, free and compulsory primary education for all children of Yobe state up to junior secondary school level through the provision of the requisite infrastructure, human resources, and required teaching-learning materials that will facilitate imparting of qualitative education in the state (YOSERA III, page 58-9).

While the above-mentioned policy declaration and subsequent other statements remain "mere political statements", certain standards are considered important while making an assessment of EDGs especially guided by the international best practices. Hence, when asked what the regime's key educational objectives were in Yobe state, an educationist whose experience ranges from once a secondary school teacher, a principal and currently a university lecturer and activist provides a background:

"For you to understand the regime's educational objectives, you have to understand that the educational policies in Yobe state just like every other state in Nigeria are not different from National Policy on Education (NPE). These national policies on education are not also far away from the global policies on education such as the MDGs. In my view, these national and international policies on education are today very relevant even in our societies. I think if they are to be properly adopted and followed sincerely we may observe some level of success in the education sector even in the case of Yobe state."

This opinion is an indication of the relevance of IEDGs on national education development planning as having been captured in EFA declaration in Jomtien in 1990, Dakar in 2000 and Korea in 2015 (Lewin, 2015; UNESCO, 2015). Specifically, there were calls in Dakar in 2000 where more than 160 countries made a commitment to pursue these six EFA goals by 2015 (Lewin, 2015). These identified goals were centered on improving early child care and foundation; universal primary education; youth and adult skills; adult literacy; gender policy and equity; and quality education. Based on its relevance, such educational goals made USAID (2011) to advance that educated citizens seems to be more supportive of the ideas and institutions of democracy which may affect public life and effective democratic decision making process through more informed public opinion. In Nigeria, since the return to democratic set up in 1999, the nation, therefore, adopted such important IEDGs. Specifically, Nigeria's NPE like the education-related MDGs have also emphasised the attainment of UBE by 2015 which each state government is expected to peruse in their respective territorial domain.

In Yobe state, to indicate the domestication of these international and national education goals under this democratic regime, this remark is worth sharing in full.

"The programs currently in operation nationwide are the Universal Basic Education, Re-branding Nigeria, Education for All and Millennium Development Goals MDGs. All these are deliberate attempts by different administrations to inculcate in the people new ideas for individual and collective development. Here in the state, we have a similar program tagged Yobe Socio-economic Reform Agenda (YOSERA). This program seeks to inculcate in our 


\section{Macrothink

people the need for value reorientation, need for education and social infrastructure, economic empowerment, etc. YOSERA document is our guiding principle and it has short and long term plans to move Yobe to a greater height. We have since realised that education is the key to the liberation of our people from the shackles of poverty, disease, hunger and squalor." (Address by H.E, Executive Governor of Yobe state, Alhaji Ibrahim Gaidam on the occasion of the 2009 International Literacy Day Celebration on $2^{\text {nd }}$ October 2009).

Although, as indicated in the remark above, the statement is a confirmation of his regime's political commitment towards domestication of IEDGs as having been advanced since EFA, MDGs and the recently SDGs. This, therefore, suggests that Yobe state government might have based on these established IEDGs developed its own peculiar EDGs. A civil society member in Yobe state aptly captured this view:

"Most of the current education policies we have in UBE and others are mostly been guided by international development objectives. But, you know in Yobe state we have our own peculiarities with regards to our own culture, religion and economic orientations in all localities. My take is that the state government must have taken into considerations these key issues in Yobe state before finally arriving at the current education development goals."

It should, however, be noted that while most of the education goals were home-driven, most of such motivations and influence majorly comes from the international development bodies and organisations. Hence, it could, therefore, be viewed that in some respects that most of the current EDGs in Yobe state are domestication, replica, and localisation of the wider context of the IEDGs. For clarity of purpose, Figure 2 below provides the strategic framework for improving education outcome through the proposed EDGs in Yobe state as subsequently explained. 


\section{Macrothink $\Delta$ institute ${ }^{\text {tm }}$}

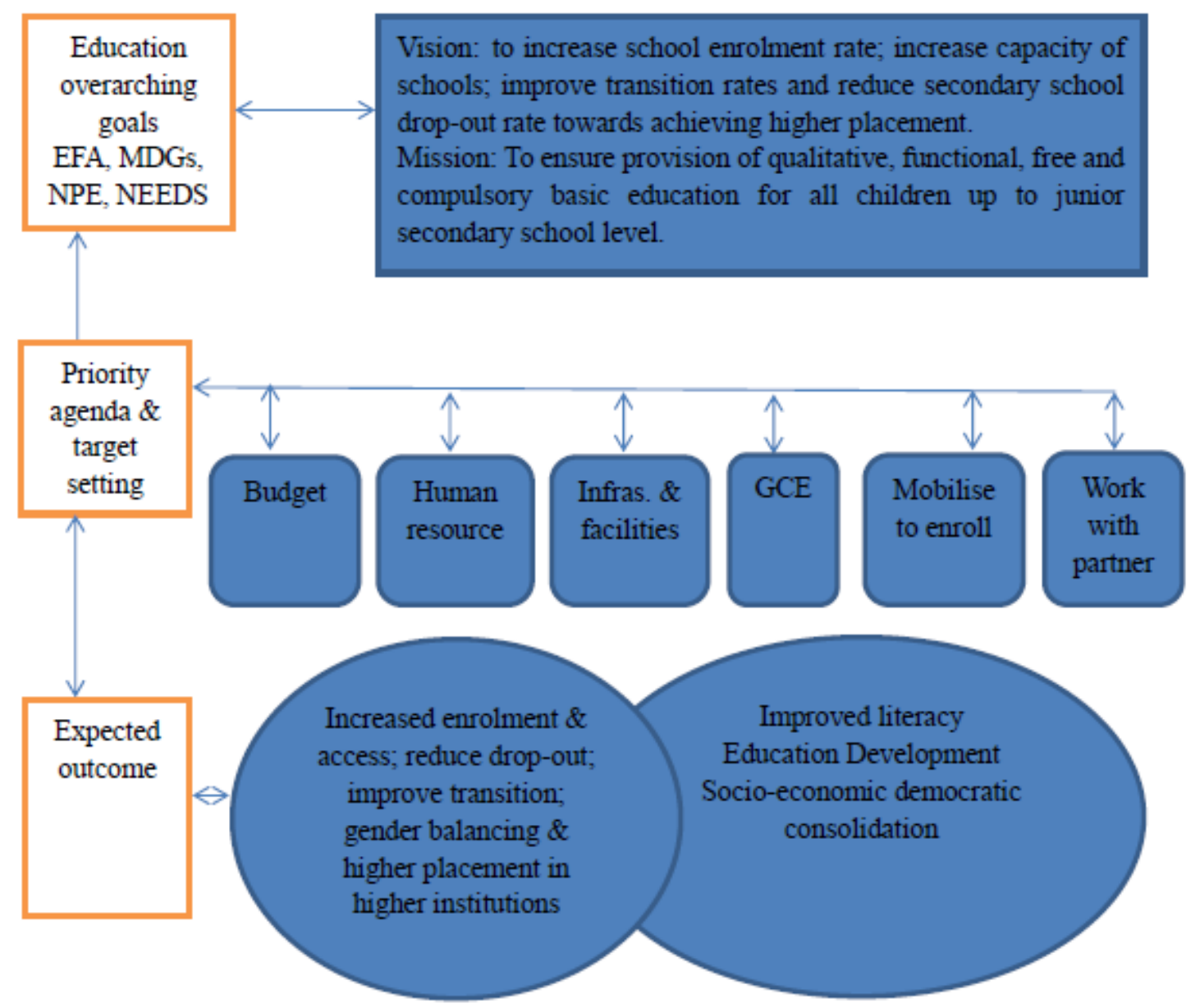

Figure 2. Strategic framework for improving education outcome through EDGs

This domestication is not surprising as education development is now generally regarded across the globe as important element towards achieving human socio-economic development in most societies. This indicates the reason both developed and developing nations alike now considers education as a priority towards improving the living standard of citizens. More so, emphasis on education development is more interesting in recent times as developing nations and democracies are struggling to meet up with MDG and SDG goals. Its key challenges, however, remain that, although there are provisions of decentralisation at state government level, education policy decision is still highly centralised at national level thus discouraging special educational initiatives and innovations that might have added value to the current system.

\subsection{Education Priority Agenda Setting}

The findings of this study reveal six key education priority agenda towards achieving education development in Yobe state and each agenda is subsequently explained.

\subsubsection{Education Budget and Financial Investment}

This regime intended to allocate and utilise more resources towards achieving the UNESCO's recommendation of $26 \%$ allocation to the education sector in Yobe state through its yearly 
budgetary allocation. In their argument, informants shared that since Yobe state has continued to be tagged "an educationally disadvantaged state", the regime's resolve to allocate more financial resources to education was not only eminent but strategic. However, some informants cautioned that Yobe state has no any noticeable Internally Generated Revenue which could possibly affect it's current and even future budget and financial investment in its educational development drive. This show that since Yobe state government is majorly dependent on federal government through monthly statutory allocation to discharge its development agenda even its educational services will be affected. Hence, the implication is that the nature of federal allocation (whether higher or lower) may likely affect the education sector in Yobe state, as there acould be no sufficient resources for the regime to execute its educational objectives.

However, despite the possible challenge that may affect the regime's intention to allocate and utilise resources in achieving the UNESCO's recommendation of $26 \%$ allocation to the education sector, the regime's objective seems relevant towards achieving socio-economic democratic consolidation. Some scholars (Carson et al., 2015; Chatterji et al., 2015) showed that public spending on education increases the quality of education outcomes. In democratic Yobe state, this effort is particularly important as records have shown that in 2009, the expenditure of education in Yobe state falls far below the recommended at least based on UNESCO's standard (YOSERA III; YBSG, 2012). Its relevance for this democratic regime is that this shortfall is more worrisome as the availability of such resources will ensure factors related to the educational performance of students and pupils such as textbooks, clean water points, toilet facilities, available teachers and classrooms are available (Carson et al., 2015). Impliedly, the regime's overall intention to increase its education budget and financial allocation is therefore considered important for the overall realisation of its education objectives in the current democratic process. Hence, more resource will mean more development for the education sector.

\subsubsection{Education Human Resource}

The development of education human resource objective of this democratic regime was geared towards achieving the recommended UNICEF and Nigeria's NPE goals (1 teacher to 40 student's ratio). To achieve this agenda, this regime aimed to achieve its objective through the development of professional teachers at a lower level; encourage on the job training of teachers particularly in the primary school levels in collaboration with the Universal Basic Education Commission (UBEC) and National Teachers Institute (NTI). Also, this regime intended to formulate Teacher Motivation Policies (TMP) and to formulate deliberate policy for special employments to NCE (National Certificate of Education) graduates. In addition, the emphasis was made on the recruitment of teachers rather than auxiliary staff and to reinvigorate the zonal inspectorate offices to carry out effective and efficient supervision across schools (YOSERA III). Overall, these agenda sets were aimed at meeting the teacher requirement gap that existed in the education sector towards filling the gap of manpower requirement in Yobe state.

This political determination seems relevant because when the regime came on board in 2009, there was a clear shortage of teachers in the education sector in Yobe state. Although this shortage of teachers is a national problem, in Yobe state, most schools were lacking sufficient 
manpower and even the existing teachers in the schools required retraining (YOSERA III). Specifically, this shortage of teachers is considered worrisome as more qualified teachers are still needed in the country and the state to meet with the increasing number of children attending schools (YBSG, 2014; MDG, 2015; UNDP, 2015). However, this acute shortage of required teachers in developing nations like Nigeria and Yobe state, in particular, is not the only challenge as importantly well qualified and trained teachers are the ones needed who are likely to improve the quality of education provided in the schools (Carson et al, 2015). Based on this, the intention of the regime towards developing education human resource is seen as an important element in education development and its relevance on socio-economic democratic consolidation in Yobe state.

\subsubsection{Education Infrastructure and Facilities}

Education infrastructure and facilities were identified as another priority objective of this regime. The motivation was that when this regime came on board in 2009, the education infrastructure and facilities in Yobe state were either overstretched or dilapidated and therefore not conducive to teaching and learning process (YBSG, 2012; YOSERA III). To address the prevalence of non-functional schools, the regime declared to rationalize primary/secondary schools through the provision of required facilities including teaching-learning materials, expansion of infrastructure such as staff quarters, classrooms, hostels, laboratories etc. This effort seems important towards improving the existing capacity of basic schools to cope with increased enrollment of school children. As most informants shared, the main objective was to provide requisite infrastructure and teaching-learning materials that will facilitate imparting qualitative and functional education and thus positively influences socio-economic democratic consolidation in Yobe state.

The relevance of education infrastructure and facilities such as classrooms, hostels, furniture, toilets, computers and ICT equipment to deliver better education result have been previously emphasised (Scheerens et al., 2011; Anyanwu, 2016; Shimeles \& Verdier-Chouchane, 2016). However, although it remains important towards achieving overall educational development, its availability may not be enough if there is no political commitment or determination of the regime in power. Hence, its provision is necessary and important as the availability and management of the facilities and instructional materials may improve teaching and learning environment in schools (Scheerens et al., 2011; YBSG, 2012). Hence, it is not only reasonable but justifiable that the current regime declared to provide, maintain and develop education infrastructure in the state as its relevance in education cannot be overemphasised as in any society. Hence, the regime agenda to create access to education through the provision of requisite infrastructure and facilities is required for quality education. In the long run, this will help bridge the increasing current gap between Yobe and the more educationally advanced states in Nigeria.

\subsubsection{Girl Child Education}

Girl Child Education was considered as another priority agenda of this regime. In 2009, when this regime came on board, female population seriously lags behind their male counterparts at all levels of the education system in Yobe state (NBS, 2010, YBSG, 2012). A top regime official thus declared "we felt it was important as a government to mainstream gender into the education system and the entire development of Yobe state". Also, YOSERA III and Yobe 
Policy documents have consistently advanced that the education of girls in Yobe state is considered crucial for the effective upbringing of children, reductions in infant and child mortalities and reduction in child malnutrition (YBSG, 2012). Hence, the regime's intention is considered relevant to socio-economic democratic consolidation as inadequate attention towards GCE will make the achievement of MDG3 (achieving gender parity in schools between boys and girls) difficult if not impossible in the state. Under this democratic regime, these efforts remain important element that democratic governments may not contemplate to deliver as the promotion of the rights of girls and women is now taking a center stage at various levels of national and international development agenda.

A previous study showed that improved education of girls who are future mothers is considered important towards reducing the prevalence of maternal and child mortality rates (Makate, 2016). Also, since MDG3 situates girls and women's empowerment in to education, even in Yobe state, it should mean tracing and choosing goals, targets, and indicators towards guiding gender policies and monitoring educational development outcomes (Sen \& Mukherjee, 2014). In addition, Anyanwu (2016) specifically advanced that the promotion of gender equality in schools is for two reasons. Firstly, girls and women's acquisition of education is important towards fighting poverty. Secondly, the opportunities that education provides to girls and women in recent times to compete with other sexes in all sphere of life are invaluable. Based on the relevance of GCE, the regime's declared agenda is important towards the actualisation of its goals, strategic objectives, and targets towards filling the gap between boys and girls enrolment in Yobe state.

\subsubsection{Campaigns and Innovations towards School Enrolment}

Mass mobilisation campaign towards increasing net enrolment rate in Yobe state was identified as another priority objective of the regime in its development goals. Hence, informants argued that since the creation of Yobe state in 1991, the state over the years seriously lags behind its counterparts in education net enrolment. Based on this shortfall, the starting point is, therefore, to engage in creating awareness campaigns by all stakeholders if anything meaningful is to be achieved. One development partner like most informants thus emphasised this point.

"For me, there should be continuous sensitisation and awareness campaign on the need and importance of both western and Islamic education in all parts of Yobe state. Yobe state remains backward largely because of the poor education system. To kick-start its development drive, the campaign for school enrollment is the key which requires the involvement of all stakeholders."

Beyond the school enrolment campaigns, the regime had initiated key innovations including free education policy; free medical treatment for boarding students; improvement in feeding in boarding schools; sponsorship of best students for future study both at home and abroad; payment of national entry examinations among several others. Therefore, the regime's overall commitment was to 1) ensure the provision of qualitative, functional, free and compulsory primary through junior secondary education for all children 2) provide required infrastructure, human resource and teaching and learning materials needed for qualitative education and 3) encourage through public engagement and enlightenment campaign by the government and stakeholders towards pursuing and supporting secondary and higher education by all citizens of Yobe state (YOSERA III:59; YBSG, 2012:38). Banking on the regime's overall intentions, 
these general goals were therefore aimed at improving school enrolment in an attempt to provide access and promote equity, quality, and gender balancing in education development in the state.

Although the nature of school enrolment is undoubtfully worst in most northern states across Nigeria, such poor enrolment of school children is not only peculiar to Yobe state. Its overall trend in Nigeria is worrisome that some serious efforts must be done to arrest this situation. For instance, recent data showed that there are at least more than 10 million out of school children in Nigeria (MDG, 2015; UNDP, 2015; UNICEF, 2015). In addition, with almost 47\% of world's proportion of out of school children, Nigeria is undoubtedly home to the largest number of out of school children anywhere globally. This case is, however, more worrisome in the northern part of Nigeria with the lowest record of school attendance rate if compared with its southern state counterparts over the past years (UNICEF, 2015). As is expected of any responsible democratic regime, the starting point in Yobe state is to, therefore, propose an acceptable EDG and see to its full implementation towards achieving its overall education targets.

\subsubsection{Education Ownership and Participation}

Although the responsibility for the initiation and implementation of EDGs at the state level generally remains with the executive arm of the state government through SMoE, the federal government, State House of Assembly, local administrations and civil societies among others play in Yobe state. To achieve this agenda, this regime intended to incraese the number of education stakeholders in the education development process. This aim was to be achieved through collaborations with key education stakeholders. This intention reflects the democratic principle of participation as has been encouraged by Nigeria's National Council on Education and even IEDGs. In Yobe state, of particular importance in education agenda development is the specific role of public officials, traditional and religious leaders, civil society organisations, international development partners, education administrators, teachers, parents, among other stakeholders. The essence of this partnership in a developing society like Yobe state is for the promotion education ownership and sustainable development that is considered invaluable in achieving education development. One development partner shared his experience.

UNICEF has been enjoying a very good relationship with the state government in Yobe especially because of UNICEF's big contribution in providing a variety of services to the communities in different LGAs. I am happy that the state government is acknowledging UNICEF's support for its communities in general. UNICEF is always sharing information on its program with all concerned at the state level and engages them in discussions and on critical issues with an aim to develop good coordination and collaboration to achieve our targets on the ground and to cover the gaps if any in an amicable way. Meetings and discussions with the government officials is an important factor for us as this helps us in understanding each other's position and helps in reaching consensus on a number of important issues towards developing education goals and objectives.

Tickly and Barret (2011) previously explained that this kind of democratic principle which encourages participation of stakeholders has an important role to play in deciding the context, structure and process of education development. Phuong Luong and Wolfgang (2014) have equally advanced that democratic participation of education stakeholders denotes the key 
principles of democracy. In what they described as "diversified stakeholders" involvement of learners, teachers, multilateral agencies, donors, corporate bodies and civil society groups are considered relevant for proper education development. Hence, stakeholders must be involved in "planning education, developing relevant and inclusive policies, strategies and standards, delivering and implementing education activities, monitoring and assessing education" (Phuong Luong \& Wolfgang, 2014:185). In short, this involvement of stakeholders emphasise democratic decentralisation and participation of education system and meeting the social and individual education needs of each society. This means that this participation will henceforth motivate stakeholders to have a sense of ownership important towards the achievement of the sustainability of such EDGs in Yobe state. The lack of such involvement may also have its likely consequences and challenges which may not augur well for the development of the education sector and socio-economic democratic consolidation.

\subsection{Education Target Setting}

A previous study (Phuong \& Wolfgang, 2014) has shown that education targets setting help towards monitoring and assessing education progress. Therefore, since monitoring is vital for ensuring education process in regime performance, political regimes must, therefore, prioritise its current and future targets. To achieve its education agenda, the democratic regime must thus indicate some level of political commitment and determination towards actualising its goals and targets towards providing the educational needs of citizens. Based on this, these strategic objectives can only be achieved if appropriate targets were put in place towards realising the regime's overall EDGs. At the time when this regime came into power in 2009, Barret (2011) showed that 2008 marked the midway juncture between initial target years of the MDGs. This means that along this juncture a group of scholars have suggested that a new approach should emphasise on a human-centered approach that has a qualitative set target at national levels involving a wide range of stakeholders.

Importantly, to indicate the relevance of decentralisation of education target setting Barret (2011) argued that goals for access to education should have targets tailored to the national context, or in the case of large federated nations, sub-national context might include targets across various educational levels. This is therefore not surprising that in a federating political system such as Nigeria democratic regime at various level of governance structure (federal, state and local governments) is thus expected to improve education systems by first initiating their respective EDGs. Hence, in an effort towards achieving the Yobe state government objectives from 2009-2015 in the current democratic process, the following education key targets are identified by informants and also contained in YBSG (2012:41) and YOSERA III page. 59-61.

Increase enrollment rate into primary schools to $75 \%$ by 2015

Increase the capacity of schools to cope with increased enrollment by $35 \%$ by 2015

Reduce gender gap in primary schools by $50 \%$ by 2015

Ensure that by 2015 , children everywhere, boys and girls alike will be able to complete a full course of primary schooling

Eliminate gender parity at primary and secondary education preferably by 2015

Increase spatial distribution of primary schools by $55 \%$ by 2015 
Increase enrolment rate in secondary schools by $60 \%$ by 2015

Reduce secondary school drop-out rate by $50 \%$ by 2015

Reduce gender in balance in secondary enrolment by $35 \%$ by 2015

Increase transition rates from primary to junior/secondary schools by $50 \%$ by 2015

Increase the capacity of schools to cope with increased enrollment by $55 \%$ by 2015

Achieve $75 \%$ placement rate in higher education to enable Yobe state to fill its quota in the tertiary institutions in the country

A general reflection of these targets showed that the key EFAs and MDGs have provided a motivating framework as endorsed by UN member states (Lewin, 2015). In Nigeria and by extension in Yobe state, this case is not different. In essence, such global (EFA and MDGs) and national targets (NPE, NEEDS, and UBE) thus provided the architecture of the current target set by this regime. On a positive note, these targets in Yobe state provided the baseline through which current and future EDGs could be formulated, targeted, evaluated, measured and reformed. It will also serve to explore the accountability of this democratic regime since Lewin (2015) argued that intentions are mostly found in goals and judgments at the extent of performance. For future development as Lewin (2015) suggested, these current targets will in Yobe state and other similar developing areas provide the windows to identify new priorities after revisit and assessment of the existing ones.

On a negative note, while these education targets were mostly optimistic, in most cases there is a lack of clarity in terms of what could be used to measure targets (Lewin, 2015) as percentages were not clearly defined to determine school enrolment, retention and transition rates as can be easily measured in gender parity for the ratio of boys and girls in schools. Hence, how to measure or analyse increase or decrease in terms of percentages used in the targets are still contentious as there is no consistent threshold adopted in Yobe state. Similarly, in primary school enrolment, while YOSERA III proposed 50\% as its target, YBSG (2012) another policy document of this same regime, on the contrary, proposed 75\%. Other inconsistencies observed are in percentages of enrollment in schools, school drop-out to be curtailed and transition rates, among others. In short, beyond the regime's failure to clearly define the step by step target for education finance and human resource development, such emergency situations like the current insurgency caused by Boko Haram and the plans to address them, depicts lack of stability in policy targeting which may pose some challenges on how best to measure achievements in education development in Yobe state.

Based on the above key limitations, these indicators are sometimes ambiguous, flawed and inconsistent while making effort for interpretation (Lewin, 2015). Hence, these remain as limitations to usage in key targeting in most cases in Yobe state. It should, however, be noted that although this remains the general trend, such development efforts will be dependent upon the peculiar nature and priorities the regime offer while piloting machinery of the government in delivering education development programmes. Interestingly, also In Yobe state, despite its identified deficiencies, the regime's targets are mostly developed to serve as "milestone on time bound pathways" (Lewin, 2015) in achieving education overall goals and objectives. This will generally mean that for education development indicators to be useful even in Yobe state they must work in a "logical relationship" with goals, objectives, and targets towards 
achieving proper planning and monitoring progress (Lewin, 2015). Infact, this will serve as a future baseline to determine what has been achieved or not in the current process. In short, the regime's EDGs will continue to remain significant towards the achievement of education development in Yobe state and the impact it may have on overall socio-economic democratic consolidation.

\section{Conclusions}

This paper provided the general description and analysis of EDGs of Gaidam's regime from 2009-2015 through the perceptions and experiences of informants and education stakeholders in the current democratic process in Yobe state. As the findings revealed, the regime intended to increase its education budget and finance; recruit, develop and retain education human resource; upgrade existing and provide new infrastructure and facilities; mainstream gender balancing and strengthen mobilisation of stakeholders in education development supported by the partnership and the participation of stakeholders. The addressed issues in this paper remained the stabilising political factors in regime performance within its constitutional mandate which envisaged comprehensive EDGs towards improving education access, equity, quality and gender balancing in in Yobe state. As is the case with most IEDG goals, in Yobe state these goals remain fundamental as most of the schools are still without required funding, human resource, infrastructure, gender balancing, poor enrolment and poor partnership. In this vein, it means citizen's basic education needs and demands which are shared by citizens cannot be achieved if the goals are not well crafted towards achieving education development. Hence, the regime's political commitment towards reinvigorating education development is important not only for making significant progress in achieving the MDGs, but also as critical for the future and current development of Yobe state. Impliedly, the regime's performance in EDGs will be influenced by the existing content and context of its key development agenda which may either positively or negatively affect its socio-economic democratic consolidation. Overall, as the finding has mapped out the mandates, objectives, priority agenda and target settings towards achieving education development set by this regime, the important future question still remains whether or not such declarations and formulation of EDGs were achieved or not in reality. Hence, future studies could be undertaken to assess the impact of the regime performance in key education outcomes in relation to the already declared education goals set by the regime.

\section{Acknowledgement}

This paper is based on a wider empirical study conducted by the first author for his doctoral degree at the Universiti Putra Malaysia from 2014 to 2017 supported by the co-authors in the entire research process. The authors are grateful to all the informants for their participation in the study. Similarly, we acknowledge the Yobe State Ministry of Education (YBMoE) for providing vital information for this study.

\section{References}

Abbas, A. I. (2013). Post military era and the challenges of democratic governance in Nigeria, Africa-Dynamics of Social Science Review, 4(4), 56-70.

Abbas, A. I. (2016). Between policy expectations and realities of poverty reduction efforts: An assessment of National Poverty Eradication Programme (NAPEP) in Yobe State, Nigeria. 
Journal of Social Science for Policy Implications, 4(1), 37-62. https://doi.org/10.15640/jsspi.v4n1a3

Anyanwu, J. C. (2016). Accounting for gender equality in secondary school enrollment in Africa. African Development Review, 28(2), 170-191. https://doi.org/10.1111/1467-8268.12188

Barrett, A. M. (2011). An education millennium development goal for quality: complexity and democracy. Compare: A Journal of Comparative and International Education, 41(1), 145-148. https://doi.org/10.1080/03057925.2011.534853

Chatterji, M., Mohan, S., \& Dastidar, S. G. (2015). Determinants of public education expenditure: evidence from Indian states. International Journal of Education Economics and Development, 6(1), 1. https://doi.org/10.1504/IJEED.2015.068355

Carson, L., Noronha, J. V, \& Trebilcock, M. J. (2015). Held back: Explaining the sluggish pace of improvement to basic education in developing democracies - The Cases of India and Brazil. Journal of Poverty Alleviation and International Development, 6(2).

Fukuda-Parr, S., Yamin, A. E., \& Greenstein, J. (2014). The power of numbers: A critical review of millennium development goal targets for human development and human rights. Journal of Human Development and Capabilities, 15(2-3), 105-117. https://doi.org/10.1080/19452829.2013.864622

Lewin, K. M. (2015). Goals and indicators for education and development: Consolidating the architectures.

Makate, M. (2016). Education policy and under-five survival in Uganda: Evidence from the demographic and health surveys. https://doi.org/10.3390/socsci5040070

MDG. (2010). Nigeria 2010 Millennium Development Goals Report. MDG: Abuja.

MDG. (2015). Millennium Development Goals Report. United Nations, 72.

National Bureau of Statistics (2010). Poverty profile for Nigeria. Abuja: National Bureau of Statistics.

NPC (National Population Commission) \& ICF Macro (2008). Nigeria Demographic and Health Survey 2008. Abuja, Nigeria/Calverton, MD USA: National Population Commission and ICF Macro.

Phuong, M., \& Wolfgang, L. (2014). Conceptualizing Quality Education from the Paradigm of Recognition. Jourmal of Education and Practice, 5(18), 178-192.

Pranevičienè, B., \& Margevičiūtè, A. (2015). Challenges To The Implementation Of Institutional Reform In The Lithuanian General Education System. Baltic Journal of Law \& Politics, 8(1), 106-138. https://doi.org/10.1515/bjlp-2015-0013

Scheerens, J., Luyten, H., \& Ravens, J. (2011). Perspectives on Educational Quality. SpringerBriefs in Education. https://doi.org/10.1007/978-94-007-0926-3_2

Sen, G., \& Mukherjee, A. (2014). No Empowerment without rights, No rights without politics: gender-equality, MDGs and the post-2015 development agenda. Journal of Human Development and Capabilities, 15(2-3), 188-202. https://doi.org/10.1080/19452829.2014.884057

Shimeles and Verdier-Chouchane (2016). The key role of education in reducing poverty in 
South Sudan. African Development Review, 28, 162-176.

https://doi.org/10.1111/1467-8268.12199

Socci, C., Ciaschini, M., Toffoli, L., Ciaschini, M., Socci, C., \& Toffoli, L. (2014). Education services and reallocation of government expenditure, Int. J. Educ Econ and Devt, 6(1), 38-58. https://doi.org/10.1504/IJEED.2015.068359

Susuman, A. S. (2017). HIV/AIDS in Ethiopia: Health View. Journal of Asian and African Studies, 52(3), 302-313. https://doi.org/10.1177/0021909615570957

Tikly, L. (2011). Towards a framework for researching the quality of education in low income countries. Comparative Education, 47(1), 1-23. https://doi.org/10.1080/03050068.2011.541671

Tikly, L., \& Barrett, A. M. (2011). Social justice, capabilities and the quality of education in low income countries. International Journal of Educational Development, 31(1), 3-14. https://doi.org/10.1016/j.ijedudev.2010.06.001

UNDP. (2015). Human Development Report 2015. Work for Human Development.

UNESCO. (2015). Education for all 2000-2015: Achievements and challenges. EFA global monitoring report, Paris: UNESCO.

UNICEF. (2015). Annual Report.

Unterhalter, E. (2014). Measuring education for the Millennium Development Goals: Reflections on targets, indicators, and a post-2015 framework. Journal of Human Development and Capabilities, 15(3-Feb), 176-187.

USAID (2011) Policy brief: The impact of education across sectors: Democracy.

Yobe State Government (YBSG) (2012). Yobe Policy Document for the Implementation of programmes and projects (2011-2015)

YOSERA III (Yobe Socio-Economic Reform Agenda 2011-2015).

\section{Copyright Disclaimer}

Copyright for this article is retained by the author(s), with first publication rights granted to the journal.

This is an open-access article distributed under the terms and conditions of the Creative Commons Attribution license (http://creativecommons.org/licenses/by/3.0/). 